\title{
America Still Held Hostage: The Hostage Crisis Generation and Public Opinion about Iran Deal
}

\author{
Mazaher Koruzhde \\ Valeriia Popova \\ Department of Politics and International Relations \\ Florida International University
}

\begin{abstract}
The hostage crisis of 1979 was a defining moment in the history of US-Iran relationship that left a lasting impact on the generation of the Americans who witnessed it and deeply affected their attitudes toward Iran and Iran-related policies. In this paper, we use a case study of the Iran nuclear deal to put this idea to the test. We hypothesize that the hostage crisis generation is less likely to support the Iran nuclear deal than the post-hostage crisis generation. Using data from the 2015 Chicago Council Survey of American Public Opinion and U.S. Foreign Policy, we conduct a formal statistical analysis. The results of our OLS regression analysis show that there is a statistically significant difference between foreign policy attitudes of the two generations, irrespective of partisanship and ideology that are usually considered the main determinants of public opinion on foreign policy.
\end{abstract}




\section{Introduction}

The seizure of the American embassy in Tehran following the Islamic Revolution has been the lens through which the public in the United States as well as most politicians have been viewing Iran for the last four decades. For 444 days, “America was taken hostage," which planted the seeds of hostility, hatred, distrust, and fear in the hearts and minds of the Americans. For the generation that saw the drama unfolding before their eyes, Iran has never overcome its image of a country ruled by "mad Mullahs."

The seizure of the US embassy was the beginning of a series of shared traumatic foreign policy experiences that sculped the minds of millions of the Americans and made them a distinct cohort that we refer to as the hostage crisis generation. From 1979 on, the hostage generation never forgot their flags being burned on the streets of Tehran, their fellow Americans being captured in the US embassy in Iran, and their soldiers dying in a failed attempt to rescue the hostages. These pictures are too bright and too vivid to fade away or be supplanted by a new narrative. Four decades later, the Iran hostage crisis still keeps shaping the hostage generation's attitudes towards the Islamic Republic.

It seems intuitive that the Americans never forgot the hostage crisis and subsequent failures of the Carter administration to deal with the issue. Yet, the idea that these events have a causal effect on people's attitudes toward Iran and US foreign policy has been neither systematically tested nor empirically confirmed. This is the task we undertake in this paper.

Our research contributes to the ongoing debate on the role of generational differences in shaping attitudes toward Iran. We analyze cross-sectional data from the 2015 Chicago Council Survey of American Public Opinion and U.S. Foreign Policy and conduct a formal statistical test 
through an OLS regression in order to reveal a generation gap created by the hostage crisis. We argue that the hostage crisis produced a notable difference between older and younger Americans. We examine how this generation gap affects individuals' attitudes to US foreign policy toward Iran - in particular, the Iran nuclear deal as arguably one the greatest achievements of the US in dealing with the Islamic Republic. We make a case that the hostage crisis has left a profound impact on the hostage generation and led them to assess all subsequent foreign policy toward Iran in retrospective light.

Furthermore, our study speaks to a broader question of formation of foreign policy attitudes. Most research explain foreign policy opinions through a prism of current events. In contrast, we approach the issue from a less conventional angle to assert that the roots of foreign policy attitudes lie in past traumatic experiences. Using Iran deal as a case study, we investigate whether the American public evaluates foreign policy achievements retrospectively, with historical events as a point of reference, as opposed to prospective evaluations with future benefits in mind. Iran deal is a groundbreaking agreement that was expected to pave a road for normalization of US-Iran relations. Moreover, it could have benefited the US in terms of national security and prevention of nuclear proliferation, therefore one would expect a widespread support for it among the Americans. We put forward an argument that a surprisingly low support for the deal can be explained by a generation gap formed by the hostage crisis and the fact that, despite positive future prospects of the deal, the public evaluates the agreement retrospectively.

This research answers two key questions. First, has the hostage crisis caused a generation gap in the American public that influences people's attitudes toward Iran deal? Second, do the Americans evaluate foreign policy achievements vis-à-vis Iran retrospectively? 
The plan of the paper is as follows. We provide a brief historical overview of two events that we claim are linked to each other through generational differences: the Iran hostage crisis and the Iran nuclear deal. We then focus on how our research fits into the existing literature on formation of foreign policy attitudes. We introduce our data and research design in the fourth part of the work followed by a presentation of hypotheses and variables. We review results of our analysis in the following part. Finally, we conclude with a detailed discussion of mechanisms that caused the generation gap.

\section{Historical overview}

\section{The hostage crisis}

On November $4^{\text {th }}, 1979$, in the aftermath of the Islamic Revolution in Iran, a group of radical Iranian students stormed the US embassy in Tehran and took 66 American hostages. The attackers released 14 hostages in a short while, but other 52 diplomats and embassy workers were being held hostage for the next 444 days.

During the entire hostage crisis, the Carter administration was all but powerless to improve the situation. The crisis coincided with the time of a presidential campaign in the United States, and Iran had become the major topic for candidates to rally around and a liability for Carter. Even though Carter repeatedly pledged to return the hostages home, he lacked a meaningful source of pressure on the new radical Iranian government. Iranian assets in the US were frozen, and all diplomatic relations with Tehran were cut, but none had any effect on the revolutionary leaders of the Islamic Republic. A failed rescue operation Eagle Claw in April 1980 claimed lives of 8 
American servicemen and, ultimately, cost Carter a presidency. In November 1980, Carter lost his electoral bid to Reagan. As the final humiliation to Carter, Iran released all 52 hostages just after Reagan was sworn into office- the result of the Algiers Accords negotiated by the Carter administration (Chun 2015).

The hostage crisis was a major blow to Iran-US relations, which, even after forty years, still have not been restored. As extreme as it was, the incident was in many ways a reaction on US reckless policies in Iran for decades. To ensure American companies' access to Iranian oil, America did not hesitate to back up Iranian dictators as long as the latter did not object American interference in Iran's domestic affairs. In 1953, the CIA planned and carried a coup that overthrew a nationalist prime minister Muhammad Mossadegh after he had announced a plan to nationalize country's oil industry. America justified the move as a necessity "of the Cold War and fear of Soviet expansion into an unstable Iran" (Limbert 2009). Following the coup, the Shah (Mohammed Reza Shah Pahlavi) regained his power. The result of the US interference was a reversal of one of the few democratic efforts in Iran and a breakout of a more emboldened dictatorship.

The Shah's dictatorship lasted for another twenty-five years and so did the America's privileged position in Iran, until it was shattered by the Islamic Revolution led by an exiled radical cleric, Ruhollah Khomeini. Khomeini's sharp criticism of the US resonated with people's support for separation from America's interests, and a battle against "the Great Satan," as Khomeini referred to the US, quickly became the center of the new regime's ideology. The last nail in the coffin was Carter's admission of the Shah to the US for cancer treatment in the fall of 1979. This provocative move further angered and antagonized radical Iranian revolutionaries who were hoping to have the exiled Shah back for trial. This decision was a political gamble by the Carter administration which "led directly to the trauma of the following weeks and months: the seizure 
of the American hostages in Tehran, the shattering of relationship between the United States and Iran, [and] the altering of strategic realities in the oil-rich Persian Gulf' (Smith 1981, 150).

Taking over the American embassy was important for revolutionaries for both practical and ideological reasons. It was widely suspected, though not true (Emery 2013), that the US planned to overthrow the new Islamic government, and that the American embassy, the "Den of Spies," was orchestrating a counter-revolutionary coup. Iranian students who carried out the attack on the embassy believed it was "a defensive action vital for consolidating the Revolution" (Emery 2013, 3). More importantly, the seizure became a symbol of both the end of a long period of unchallenged American influence in Iran and Iran's freedom from US imperialism.

The hostage crisis reversed the course of Iran-US relations. The two countries have not restored diplomatic relationships up to the date, and Iranian officials still pursue a policy of non-negotiation with "the Great Satan." Just as in 1979, thousands of regime's supporters still chant "Death to America" during rallies and Friday prayers in Iran. The hostage crisis was deeply shocking for the American people as well. Anti-Iranian sentiments were extremely popular among the Americans in the 1980s. A slogan "Deport all Iranians" became a commonplace in many anti-Iranian protests, and universities and students across the country turned hostile to Persian students (Brunner 2018).

\section{Iran Deal}


On April $2^{\text {nd }}$, 2015, Mohammad Javad Zarif, Iranian minister of foreign affairs, accompanied by official representatives of the European Union, United Nations Security Council ${ }^{1}$ (UNSC) and Germany in Lausanne, Switzerland, announced unexpected news. After prolonged negotiations for twenty months, the group reached an agreement on Iran's nuclear program, known as Joint Comprehensive Plan of Action (JCPOA), or Iran Deal. Under the agreement, economic sanctions against Iran would be lifted in exchange for the latter's reduction of nuclear facilities and complying to the terms of the non-proliferation regime established by $\mathrm{NPT}^{2}$ and $\mathrm{IAEA}^{3}$ regarding granting access to its nuclear facilities as well as elimination of enriched uranium.

The nuclear deal had an important symbolic meaning for both Iran and the US: two old enemies finally overcame multiple points of disagreement to meet at the same table and propose a preliminary plan of mutual actions. The deal was ideal for neither side, but it certainly was an equilibrium that sent an important message of hope for stabilization of relationship between the two countries.

The fate of the deal was misfortunate: just three years later, the new US administration headed by Donald Trump withdrew from the deal and tightened sanctions against Iran. As a result, tensions between the two countries have soared to an unprecedented level, culminating in speculations on a possibility of a military confrontation.

\footnotetext{
${ }^{1}$ The United States, Russia, China, France, and the United Kingdom

${ }^{2}$ Non-Proliferation Treaty

${ }^{3}$ International Atomic Energy Agency
} 


\section{How are foreign policy attitudes shaped?}

The literature suggests several possible sources of foreign policy attitudes. The most prominent argument states that public opinion is shaped primarily by ideology and reinforced by partisanship.

Prior to the Vietnam War, it was a common knowledge that "politics stops at the water's edge" and domestic partisanship differences among the general population do not affect the bipartisan foreign policy (Hughes 1978). However, after the Vietnam War, partisan differences in foreign policy preferences became increasingly obvious which propelled several authors to point at the partisan and ultimately polarized nature of foreign policy making in the US (Destler, Gelb and Lake 1984, Holsti 2004, Jeong and Quirk 2017, Schultz 2018). At the same time, the majority of scholars agree that, even though ideology and partisanship in American politics are closely related, the former has a more pronounced effect on foreign policy. It is argued that ideology dominates partisanship (Wittkopf 1986, Wittkopf 1990) and that "ideological self-identifications outweigh partisan loyalties" (Holsti 2004). The liberal-conservative ideological dichotomy typical for American voters channels the domestic "culture wars" into foreign affairs with the help of ideologically extreme politicians that often stimulates gridlock and conflict (Gries 2014). Ideological differences in foreign policy opinion are also expressed through moral sentiments where ideas of harm/care and fairness/reciprocity drive a belief in cooperative internationalism among individuals, while foundations of authority/respect, ingroup/loyalty, and purity/sanctity are linked to militant internationalism (Kertzer, et al. 2014). To sum up, partisanship and ideology are viewed as the main sources of foreign policy attitudes among both general public and opinion leaders.

Another line of research looks into religion as the main reason behind foreign policy attitudes. Ever since an alarmist conclusion about a lurking possibility of a religious "clash of civilizations" 
came forward (Huntington 1996), scholars struggled to understand whether and how religious beliefs influence foreign policy preferences. On the most general level, people tend to support foreign policy when it is framed in religious terms and as a divinely authored plan even in the face of countervailing political beliefs (Glazier 2013). When it comes to support for American policies in specific regions, such as the Middle East, the "faith factor" appears to be a powerful force behind public opinion. While support for military involvement in the Middle East is low across all other religious groups, Evangelical Christians remain strong supporters of a hawkish foreign policy (Taydas, Kentmen and Olson 2012, Baumgartner, Francia and Morris 2008, Barker, Hurwitz and Nelson 2008). The latter also tend to hold more negative views of Islam than others (Baumgartner, Francia and Morris 2008). The "faith factor" has most likely become important after the 9/11 attacks: prior to it, research indicated no significant difference among religious groups and found no evidence that religious elites played any role in American foreign policy (Jelen 1994).

Some scholars turned their attention to demographic characteristics such as gender, education, and age in efforts to discover the roots of foreign policy attitudes. Upon reviewing public opinion surveys, several political scientists noticed that foreign policy attitudes, much like matters of domestic politics, reveal a gender gap. Men and women traditionally differ on compassion issues, and in foreign policy, women are more likely to be doves and "cooperative internationalists" while men tend to be hawks and "militant internationalists" (Holsti 2004, Wittkopf 1986, Wittkopf 1990). Not only are men and women significantly divided on issues of war and peace (Baxter and Lansing 1980), but they also express different levels of support for defense spending and the use of force abroad, with women favoring it $6 \%$ less than men (Shapiro and Mahajan 1986). Such gender differences, although slightly less acute, are also observed among elites (Holsti 2004). This pattern of gender gap holds true for many countries (Togeby 1994) and is considered one of the 
most salient demographic predictors of foreign policy attitudes (Fite, Genest and Wilcox 1990). Similarly, education is argued to have a strong effect on foreign policy attitudes and be one of the of the "best-supported generalizations about foreign policy attitudes" (Holsti 2004). It was found that higher education is strongly correlated with support for internationalism (Holsti 2004), particularly its cooperative version (Wittkopf 1986, Wittkopf 1990). Age, on the other hand, is less determining for formation of attitudes. Several authors found either no or weak positive correlation between increasing age and being a hard-liner (Wittkopf 1986, Wittkopf 1990, Mandelbaum and Schneider 1979). It is most likely that age becomes an insignificant factor for foreign attitudes in comparison to partisan and ideological cleavages.

Another unsettled question is the effect of the media on foreign policy attitudes preferences. Some anecdotal evidence indicates that the media is remarkably powerful in embedding popular caricatures of the Iranians in American political culture. John W. Limbert (2009), one of the hostages, gives an example of how his young students without a first-hand experience of the crisis describe the Iranians thirty years after the event: emotional, devious, unreliable, incomprehensible, vindictive, fanatical, obsessed with religion and the past are only a few among many negative epithets assigned to the Iranians. It stands, however, in a sharp contrast to a classic argument that the American public knows very little about domestic politics and even less about foreign policy (Converse 1964, Carpini and Keeter 1996, Davidson 2009) and does not care about foreign conducts unless it involves casualties or elite disagreements (Holsti and Rosenau 1984, Mueller 1973, Zaller 1994). Logically, this claim suggests a limited role of the media in setting public opinion on foreign policy, which had been a prevailing view among scholars until the "CNN effect" was discovered. 
Today there is less doubt that the real power of the media is its ability to stir people's emotions by showing chilling pictures and footages of human suffering, violence, and drama in other parts of the world. For example, several authors acknowledged that people's emotional responses on news reports coming from Somalia put pressure on American policymakers to intervene (Sharkey 1993, Cohen 1963, Cohen 1994, Mandelbaum 1994, Roberts 1993). Power of the media to manipulate public mood seems so great at times that some scholars alert it can undermine the rationality of democratic deliberations and replace them with emotional reactions and a "loss of policy control" (Livingston 1997, Kennan 1993, Livingston and Eachus 1995). Recent research suggests that this interaction may be more nuanced: elites have an informational advantage over citizens when it comes to ordinary conducts of foreign policy, but when there is a conflict, especially an escalating one, this information gap between elites and the people narrows down, if does not disappear entirely (Baum and Potter 2008, Potter and Baum 2010). In other words, the media are a crucial actor in foreign policy as they are able to influence both elites and the domestic audience, but they do not favor one side at the expense of the other all the time. In addition, media narratives can successfully constrain democratic leaders from initiating hostile actions overseas (Baum and Potter 2015, Potter and Baum 2013), but they also can destabilize public opinion and undercut commitments abroad (Baum and Potter 2019).

Finally, a handful of scholars contended to interpret foreign policy attitudes through a prism of generational changes. This thesis has received mixed support because generation is confused with age all too often, and the latter, as noted above, is not the best predictor of foreign affair preferences. For example, Mannheim (1952) admitted that generational changes were among the main factors behind differences in social beliefs, yet he interpreted generation as people belonging to the same age group. Generation as a term has been used rather inconsistently: we can understand 
generation as a group of people of the same age (for instance, millennials and generation $\mathrm{Z}$ compose two distinct generations based on the year of birth) or treat all adult contemporaries, regardless of their age groups, as one generation (such as the 9/11 generation or the hostage-crisis generation). The former definition is revolved around age, the latter is around events. Many researchers (Wittkopf 1990, Mandelbaum and Schneider 1979) found no difference in foreign policy attitudes between generations because they interpreted age as a function of generation and left out the question of historical experiences shared across several age groups simultaneously. As a result, generational replacement was deemed important for the formation of social and cultural attitudes but not for individuals' opinions on foreign policy (Mayer 1992), and nowhere as influential as partisan and ideological preferences (Holsti 2004).

Yet, there is a clear connection between generations and "the lessons of history" in a sense that "members of each generation view the world in the light of critical events that marked their coming to maturity" (Holsti 2004). This linkage has not been explored well enough, but some scholars (Roskin 1974) suggest that foreign policy attitudes, or paradigms, have a cyclical nature and shift at approximately generational intervals linked to dramatic experiences in the past. In this study, we built upon the generational tradition of research to deepen our understanding of how critical events in the past are able to deeply influence people's attitudes decades after they occur. Despite a nearly universal consensus among scholars that foreign policy attitudes among the Americans can be explained by partisanship and ideology alone, our study intends to show that other powerful factors, particularly generation gaps, also play a crucial role.

\section{Hypothesis}


The hypothesis of this research is built upon the often overlooked and marginalized generational effect argument in the literature on foreign policy opinion, which is unproportionally dominated by partisanship and ideology arguments. Using the US-Iran relationship as a case study, we suggest that belonging to the hostage generation shapes and dictates foreign policy attitudes toward Iran for the entire lives of individuals, irrespective of their partisan and ideological preferences. Our research hypothesis is as follows:

Individuals who belong to the hostage crisis generation, are less likely to favor and support Iran deal than individuals from the post-hostage crisis generation.

As our main hypothesis is informed by the literature on sources of foreign policy opinion, we identified several alternative explanations proposed by other scholars such as partisanship, ideology, gender, education, religious affiliation, and media exposure. We include all these factors in our model as control variables. However, we did not develop any additional hypotheses because these factors are of secondary interest to us, and the main puzzle we are investigating is the generational effect on foreign policy attitudes.

\section{Data}

We used a dataset from the 2015 Chicago Council Survey of American Public Opinion and U. S. Foreign Policy. Unfortunately, we could not take advantage of analogous surveys from other years because they did not include a question of attitudes to Iran deal. We therefore had to limit our research to the 2015 survey, which in fact gave us a slight advantage. The time when the survey was taken (May-June 2015) is particularly beneficial for our work because it was in the midst of 
Iran deal negotiations. It provides an excellent opportunity to delve into the question of media influence. Given that Iran deal was featured prominently in mass media around that time, we have a solid ground for assuming that the media were most likely to have contributed to public opinion on the topic. Furthermore, Iran deal was arguably the most important achievement of the Obama administration that year, and it received a lot of attention from the people. Applying data restrictions based on variables of our interest, we narrowed the analytic sample down to 932 observations (adult Americans, age 18 and older). Table 1 describes sample distribution of all variables used in our analysis.

\section{Variables}

Outcome variable. There are seven questions in the survey that target respondents' attitudes toward Iran deal from different perspectives. We used them to construct one factor variable. We recoded the composite items in a way that lower values would indicate negative attitude and higher values would indicate positive sentiments towards Iran deal. This constructed attitude scale serves as the outcome variable in our study (Iran deal attitude).

This composite measurement is a significant improvement from a traditional single-item attitude scale. It consistently summarizes Iran deal attitudes across seven separate deal-liking scales into a complete and statistically advanced factor variable. The variable has an extremely high level of multi-item reliability ( $\alpha=0.9$ on Cronbach's scale) and a high eigenvalue of 3.88 .

As measured by our factor variable and shown in Table 1, the average American's attitude to the deal is not favorable (.005 on normalized scale with standard deviation of .95 ). 
Independent variable. Our study explicitly focuses on the effect of generational changes on foreign policy attitudes and preferences. We constructed this variable by calculating the age of respondents in 1979 based on their age in 2015 . We then created a dummy variable in which " 0 " corresponds to being 18 or less years old (we refer to this group as the post-hostage crisis generation) and "1" indicates being over 18 years old in 1979 (the hostage crisis generation). The age of 18 years old was chosen as a watershed point between adolescence and adulthood. We believe that eighteen is around the time when teenagers start going to college and become more open to the world of politics through learning new subject, encountering new viewpoints, and establishing new and diverse contacts. We also assumed that people who came of age in 1979 were more likely to follow the news and become familiar with the hostage crisis than their younger fellows. Choosing 18 years old as the dividing line between the abovementioned generations was a tentative decision based on common sense, but it was ultimately verified. Our analysis confirms that generational discrepancies in foreign policy attitudes and preferences fall exactly between the two age groups (as in 1979). To exclude a possibility of a theoretical error, we ran an additional regression analysis with an interval independent variable that created generational clusters based on a 5-year incremental interval. Surely enough, we arrived into the same result that showed a gap in foreign policy attitudes between those who were less than 18 years old and those who were over 18 years old in $1979 .{ }^{4}$

\footnotetext{
${ }^{4}$ See results in Appendix A.
} 
Covariates. As discussed in the literature review, there are several factors popularly linked to foreign policy attitude formation. Starting with the Vietnam war, partisanship and ideology emerged as the main determinants of foreign policy attitudes and preferences (Destler, Gelb and Lake 1984, Holsti 2004, Jeong and Quirk 2017, Schultz 2018). A more elaborated version of the argument suggests that ideology has a more pronounced effect than partisanship (Gries 2014, Wittkopf 1986, Wittkopf 1990). Individuals' partisanship and ideology are included in our analysis as the main control variables, each measured as a 7-category nominal scale (Republican-Democrat and extremely conservative-extremely liberal, respectively).

In addition, we control for religion as the current state of the literature suggests that religious and foreign policy preferences may correlate (Glazier 2013) and that Evangelical Christians tend to favor "hawkish" policies in the Middle East more than other religious confessions (Baumgartner, Francia and Morris 2008, Taydas, Kentmen and Olson 2012). The original dataset does not distinguish between different branches within Christianity, but it lists all major religions in the world. Because we are interested in the effect of Christianity, we created a dichotomous variable that separates Christian believers from adherents of all other religions. Unfortunately, our sample did not include a sufficient number of Muslims to contrast their foreign policy attitudes with those of Christians, therefore we limited our analysis to the difference between Christians and non-Christians.

Furthermore, we control for such demographic variables as gender and education as potential determinants of foreign policy opinion. Similar to many issues of domestic politics, men and women have been argued to have different foreign policy preferences, with women favoring more peaceful policies (Fite, Genest and Wilcox 1990, Holsti 2004, Shapiro and Mahajan 1986, Wittkopf 1986, Wittkopf 1990). Likewise, higher education has been linked to higher support for 
internationalism (Holsti 2004, Wittkopf 1986, Wittkopf 1990). We created a dummy variable for gender, and we used a 4-category ordinal variable in the dataset indicating individual's level of education, ranging from less than high school to a bachelor's degree.

Our last but not least covariate is media exposure. There is an ongoing debate about the power of media to influence people's foreign policy attitudes, with equally strong arguments in favor of (Cohen 1963, Cohen 1994, Limbert 2009, Mandelbaum 1994, Sharkey 1993) and against it (Holsti and Rosenau 1984). The most recent research suggests that power of the media is conditional upon different stages of international conflicts (Baum and Potter 2008, Baum and Potter 2015, Baum and Potter 2019, Potter and Baum 2010, Potter and Baum 2013). The role of the media is particularly important for our case as multiple media outlets were extremely active in engaging ordinary Americans with the hostage crisis in 1979. ABC ran daily late-night updates and developments of the crisis, which became known as "Nightline." CBS, too, made the crisis the central focus of its news program hosted by Walter Cronkite (Houghton 2001). To control for the media effect, our analysis features a 4-category ordinal variable of self-reported interest in news about US relationships with other countries that serves as a proxy measurement of media exposure in the model. Table 1 contains summary statistics of all variables in the analysis.

Table 1. Sample description $(N=932)$

\begin{tabular}{|c|c|c|}
\hline & Mean & $\mathrm{SD}$ \\
\hline Iran Deal Attitude Scale & .005 & .95 \\
\hline \multicolumn{3}{|l|}{ Age in 1979} \\
\hline 18 years old and less (hostage crisis generation) & $51.07 \%$ & \\
\hline 19 years old and more (post-hostage crisis generation) & $48.93 \%$ & \\
\hline \multicolumn{3}{|l|}{ Following news } \\
\hline Do not follow & $7.08 \%$ & \\
\hline Hardly interested & $13.63 \%$ & \\
\hline Somewhat interested & $43.88 \%$ & \\
\hline
\end{tabular}




\section{Christian}

Yes

No

\section{Political ID}

Strong Republicans

$14.91 \%$

Not Strong Republican

Lean Republican

$8.26 \%$

Independent

$17.60 \%$

Lean Democrat

$8.05 \%$

Not Strong Democrat

$18.35 \%$

Strong Democrat

$16.85 \%$

\section{Ideology}

Extremely Conservative

$5.69 \%$

Conservative

$22.75 \%$

Slightly Conservative

$11.59 \%$

Moderate

$33.80 \%$

Slightly Liberal

$11.27 \%$

Liberal

$11.59 \%$

Extremely Liberal

Male

$48.82 \%$

\section{Level of education}

Less than high school $\quad 6.22 \%$

High school $\quad 29.83 \%$

Some college $\quad 29.72 \%$

Bachelor`s degree or higher $\quad 34.23 \%$

Source: Chicago Council Survey of American Public Opinion and U. S. Foreign Policy 2015.

\section{Research design}

There are three regression models in our research. Model 3 represents the focus of this study which is the effect of belonging to the hostage crisis generation on attitudes toward Iran deal. It includes all the variables described in Table 1. Additionally, Model 1 tests an isolated effect of ideology and partisanship in order to check the validity of the claim that they are the main (and often only) 
drivers of foreign policy attitudes among the Americans (Holsti 2004). Model 2 examines whether the effect of the generation gap holds up controlled for ideology and partisanship.

To provide a clearer and more detailed picture of relationships between these three variables and the outcome variable, we explore their effect not only on the final factor variable, Iran deal attitude, but also on its component parts.

Table 2 presents conditional means of Iran deal attitude by the hostage crisis generation, ideology, and partisanship. We can observe several patterns. First, on normalized scale, the average of people who were at least 19 years old at the time of the Islamic Revolution and the hostage crisis is 0.18 standard deviation below the sample mean. In contrast, the average of people who were 18 years old or younger in 1979 is 0.18 standard deviation above the sample mean. This gap indicates that the hostage crisis generation is on average less confident in Iran deal than the post-hostage crisis generation. What is even more promising is that this pattern holds consistently across all seven components of the deal liking factor. Thus, the initial descriptive results are well in line with our main hypothesis.

Second, we see a linear pattern between partisanship and Iran deal attitudes. Republicans on average are less confident in the deal than Democrats ( -0.37 and 0.32 below and above the sample mean, respectively). The difference between Strong Republicans and strong Democrats alone is even starker: it is -0.47 and 0.53 respectively. Likewise, this pattern is consistent across all seven elements of the outcome variable. Third, the ideology argument is also supported by the initial descriptive analysis. Conservatives' average is -0.35 , while liberals' is 0.49 , which demonstrates that the former are significantly less supportive of the deal than the latter. Once again, the relationship is remarkably consistent across the key components of the Iran deal variable. 
To sum up, Table 2 confirms a strong and consistent effect of the key predictors on Iran deal attitude. These results indicate that our expectations are well supported by the actual data. However, these promising results emerged out of the descriptive part of the analysis, and our further step is to check whether we can generalize our findings to the US population. In order to test our hypothesis, we run several regressions. Since the outcome variable is a linearized scale that effectively summarizes the common variance across seven ordinal variables measuring various aspects of individuals' Iran deal attitudes, the natural choice of modeling is an OLS regression, the results of which are discussed in the next part of the paper.

Table 2. Iran deal attitude* by key predictors $(N=932)$

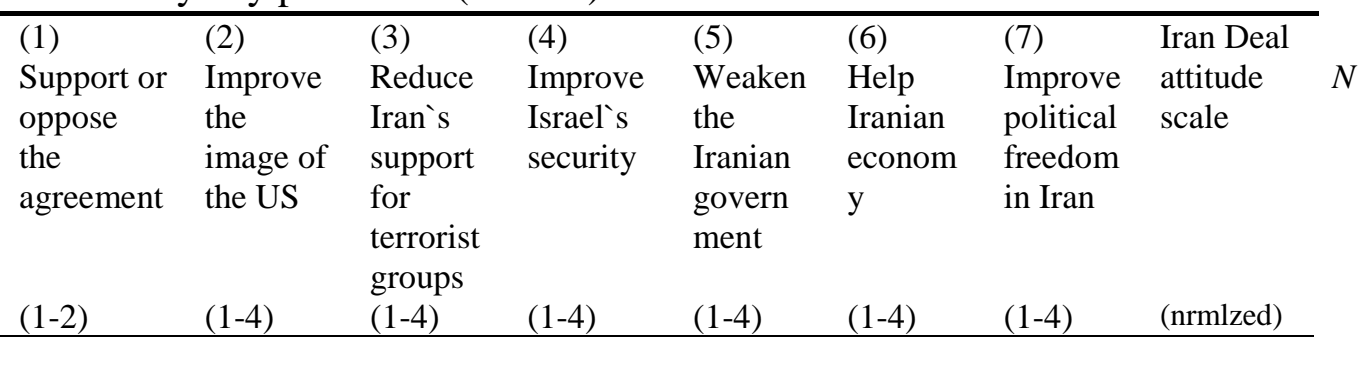

\section{Age in 1979}

18 and less

$1.68 \quad 2.30$

2.11

2.24

2.06

2.42

2.18

.18

476

generation)

19 and more

1.56

2.09

1.78

1.95

1.85

2.37

1.87

$-.18$

456

crisis generation)

\section{Political Identification}

Strong Republican

Not-strong

Republican

Lean Republican

Independent

Lean Democrat

Not-strong

Democrat

Strong Democrat

$1.38 \quad 1.81$

$\begin{array}{ll}1.38 & 1.81 \\ 1.61 & 2.16\end{array}$

\subsection{8}

1.93

\subsection{9}

2.12

\subsection{6}

2.06

\subsection{9}

2.38

1.70

$-.47$

$2.04 \quad .01$

139

$1.32 \quad 1.64$

\subsection{6}

1.62

1.59

\subsection{3}

$1.87 \quad 2.29$

1.53

$-.67$

1.96

$-.14$

2.12

2.06

2.52

$1.80 \quad 2.37$

2.05

2.22

2.10

2.43

2.19

.18

.27

2.17

2.67

2.39

.53

\section{Ideology}

Extremely

Conservative

1.35

1.77

1.60

1.86

1.75

2.13

1.66

$-.46$

53

Conservative

Slightly

$1.37 \quad 1.82$
1.57

1.64

1.74

1.74

2.30

1.74

$-.44$

212

Conservative

2.06

1.84

1.97

1.86

2.31

1.91

$-.16$

108 


\begin{tabular}{llllllllll} 
Moderate & 1.69 & 2.28 & 2.05 & 2.18 & 2.04 & 2.35 & 2.08 & .11 & 315 \\
Slightly Liberal & 1.81 & 2.41 & 2.12 & 2.32 & 2.07 & 2.49 & 2.25 & .29 & 105 \\
$\quad$ Liberal & 1.87 & 2.65 & 2.25 & 2.48 & 1.14 & 2.62 & 2.35 & .49 & 108 \\
Extremely Liberal & 1.74 & 2.80 & 2.41 & 2.54 & 2.25 & 3.06 & 2.61 & .70 & 31 \\
Total & 1.62 & 2.20 & 1.96 & 2.10 & 1.96 & 2.40 & 2.03 & .005 & 932 \\
& & & & & & & & & \\
\hline
\end{tabular}

Source: 2015 Chicago Council Survey of American Public Opinion and U. S. Foreign Policy.

Notes: items 1-7 are recoded into scales that associate lower values with negative attitudes toward Iran deal, and higher values with positive attitudes.

* Factor scale extracted from items 1-7.

\section{Regression Results}

We ran three regression models. Model 1 tested the effect of well-known predictors of foreign policy attitudes- partisanship and ideology. To stay in line with the argument that the two influence foreign policy attitudes more than any other factors, we exclude all control variables from this model. As shown in Table 3, attitudes to the deal of both Republicans and Democrats significantly differ from those of Independents. Without controlling for other factors, Strong and Not Strong Democrats score positive coefficients of 0.49 and 0.34 , respectively, on the deal attitude scale, indicating that Democrats are indeed more likely to support Iran deal. Republicans on average exhibit the opposite pattern of expressing less support for the deal. However, model 1 reveals that there is no consistent pattern across categories of Republican supporters: Strong Republicans' coefficient of -0.05 is statistically not distinguishable from that of Independents, and Not Strong Republicans tend to support the deal almost as much as Not Strong Democrats (0.30). Moreover, Leaning Republicans' coefficient of -0.35 suggests that of all Republicans, this group is the least supportive of the deal. This pattern goes contrary to the partisanship argument, according to which we should expect a consistent increase in the deal liking moving from Strong Republicans to Strong Democrats. It is perfectly normal if Leaning Democrats and Republicans are not quite 
different from independents due to the fact that their partisan preferences are not solid and stable - for instance, in model 1, Leaning Democrats' attitudes toward Iran deal are not statistically different from Independents'. Such inconsistency on the Republican side casts a serious doubt on the idea of influence of partisanship on foreign policy attitudes. It seems that strong partisanship preferences indeed account for increasing support for the deal among Democrats, but this pattern does not hold up among Republicans. Thus, the argument put forward by other scholars who linked partisanship and foreign policy attitudes is only partially confirmed in the analysis.

On the other hand, we observe a perfectly linear pattern for ideology: coefficients consistently climb up as we move from Extremely Conservatives (-0.01) to Extremely Liberals (0.7). In other words, the more liberal individuals are, the more likely they are to support the deal. Combined with the weak results for partisanship as discussed above, it seems convincing that ideology, indeed, is a more powerful predictor of foreign policy attitudes than partisanship (Wittkopf 1986, Wittkopf 1990, Holsti 2004).

Model 1 demonstrates a pure effect of partisanship and ideology on Iran deal attitudes without regards to alternative factors such as the influence of generational shifts. Model 2 is designed to account for the latter. It tests our main hypothesis that being over 18 years old in 1979 is negatively correlated with support for the deal. Table 3 demonstrates that there is indeed a significant difference between the hostage crisis and post-hostage crisis generations. On average, the crisis generation scores 0.3 lower than the post-hostage crisis generation, and this difference holds up at the level of $99.9 \%$ probability. Additionally, the explanatory power of model 2 is superior to that of model 1: a postestimation test that we ran to compare the two models' goodness of fit scores yields a $\mathrm{p}=0.00$. Model 2 provides an empirical support for our main hypothesis and reveals that 
the effect of the generation gap on Iran deal attitude holds up even in the presence of partisanship and ideology, which have long been thought of as the only drivers of foreign policy opinion.

Finally, model 3 estimates the generation effect on Iran deal attitudes controlling for other variables of interest as informed by the literature on sources of foreign policy opinion. In addition to partisanship and ideology, the impact of which is tested in models 1 and 2 and discussed above, model 3 factors in education, Christianity, gender, and exposure to media. For the purpose of this analysis, we have not put forward any hypotheses regarding these control variables as these variables are not in our immediate focus. We include them in the analysis is pursuit of scientific rigor: as discussed above, these factors are featured in the literature as somewhat plausible sources of foreign policy opinions. Model 3, therefore, is the most sophisticated and rigorous of all the three models because it accounts for the major competing explanations of foreign policy attitudes. As shown in Table 3, partisanship and ideology keep their significance, but neither education nor Christianity nor gender have any significant effect on foreign policy opinion. Media exposure, on the other hand, has a profound impact on foreign policy attitudes, with those who are somewhat interested in news about foreign countries having the highest score on the deal liking scale (0.4). More importantly, the inclusion of the covariates does not undermine the effect of the generation gap on the dependent variable - it retains its significance with a -0.33 coefficient on a highly significant level. The model has an $R^{2}=0.21$ which is, once again, a statistically significant improvement from Model 2.

Thus, model 3 provides a solid empirical ground for our hypothesis that the hostage crisis generation is less likely to favor and support Iran deal than the post-hostage crisis generation. Our findings demonstrate that the literature on foreign policy attitude formation mistakenly excludes generation as a powerful factor. This model also provides a statistical support to the assumption 
that the turmoil of 1979-1981 has a causal effect on the Americans' attitudes toward Iran decades later.

As the means of robustness check, we ran an additional regression on foreign policy preferences as the outcome variable. This variable is a factor composed of six items from the original survey measuring the Americans' Iran foreign policy preferences, ranging from military to diplomatic actions. Similar to the results of the main regression, there is a statistically significant difference between the hostage crisis and the post-hostage crisis generations, with the former preferring more hawkish policies. It shows that there is consistency in the hostage crisis generation's attitudes and policy preferences toward Iran, which reinforces the results of our analysis and further confirms our hypothesis. ${ }^{5}$

In the next section, we will discuss the results of the analysis in greater detail and lay out the factors that are crucial for explaining the effect of the generation gap on Iran deal attitudes.

Table 3. OLS models predicting Iran deal attitudes $(N=932)$

\begin{tabular}{|c|c|c|c|c|c|c|}
\hline & \multicolumn{2}{|c|}{ Model 1} & \multicolumn{2}{|c|}{ Model 2} & \multicolumn{2}{|c|}{ Model 3} \\
\hline & $\overline{\text { Coef. }}$ & s.e. & $\overline{\text { Coef. }}$ & s.e. & Coef. & s.e. \\
\hline $\begin{array}{l}\text { Hostage crisis } \\
\text { generation (ref=post- } \\
\text { hostage crisis generation) }\end{array}$ & & & $-0.30 * * *$ & 0.05 & $-0.33 * * *$ & 0.06 \\
\hline \multicolumn{7}{|l|}{ PID (ref=indep) } \\
\hline Strong Rep & -0.05 & .11 & -0.05 & 0.11 & -0.07 & 0.11 \\
\hline Not strong Rep & $0.30^{* *}$ & .10 & $0.30 * *$ & 0.10 & $0.30 * *$ & 0.10 \\
\hline Lean Rep & $-0.35 * *$ & .12 & $-0.32 * *$ & 0.12 & $-0.32 *$ & 0.12 \\
\hline Lean Dem & 0.23 & .12 & $0.25^{*}$ & 0.12 & $0.24 *$ & 0.12 \\
\hline Not strong Dem & $0.34 * *$ & .09 & $0.37 * * *$ & 0.09 & $0.34 * * *$ & 0.10 \\
\hline Strong Dem & $0.49 * * *$ & .11 & $0.54 * * *$ & 0.11 & $0.50 * * *$ & 0.11 \\
\hline
\end{tabular}

${ }^{5}$ See results in Appendix B. 


\begin{tabular}{|c|c|c|c|c|c|c|}
\hline Ideology (ref=ext.cons) & & & & & & \\
\hline Cons & -0.01 & .13 & 0.04 & 0.13 & 0.04 & 0.13 \\
\hline Slightly cons & 0.12 & .15 & 0.17 & 0.15 & 0.16 & 0.15 \\
\hline Moderate & $0.39 * *$ & .14 & $0.39 * *$ & 0.14 & $0.38 * *$ & 0.14 \\
\hline Slightly lib & $0.46^{* *}$ & .16 & $0.43^{* *}$ & 0.16 & $0.45^{* *}$ & 0.16 \\
\hline$L i b$ & $0.52 * *$ & .16 & $0.51 * *$ & 0.16 & $0.52 * *$ & 0.17 \\
\hline Ext.lib & $0.70 * *$ & .21 & $0.65^{* *}$ & 0.21 & $0.69 * *$ & 0.21 \\
\hline $\begin{array}{l}\text { Christianity (ref=non- } \\
\text { Christian) }\end{array}$ & & & & & 0.02 & 0.07 \\
\hline Male (ref=female) & & & & & 0.09 & 0.06 \\
\hline $\begin{array}{l}\text { Media exposure } \\
\text { (ref=don't follow) }\end{array}$ & & & & & & \\
\hline Hardly interested & & & & & $0.27 *$ & 0.13 \\
\hline Somewhat interested & & & & & $0.40 * * *$ & 0.12 \\
\hline Very interested & & & & & $0.33 * *$ & 0.12 \\
\hline $\begin{array}{l}\text { Education (ref=less than } \\
\text { high school) }\end{array}$ & & & & & & \\
\hline High school & & & & & -0.14 & 0.13 \\
\hline Some college & & & & & -0.16 & 0.13 \\
\hline Bachelor's & & & & & -0.24 & 0.13 \\
\hline Intercept & -0.45 & 0.14 & -0.33 & 0.14 & -0.43 & 0.20 \\
\hline$R^{2}$ & 0.17 & & $0.19 * * *$ & & $0.21 *$ & \\
\hline$N$ & 932 & & 932 & & 932 & \\
\hline
\end{tabular}

Source: 2015 Chicago Council Survey of American Public Opinion and U. S. Foreign Policy 2015. Notes: $* \mathrm{p}<0.05, * * \mathrm{p}<0.01, * * * \mathrm{p}<0.001$

\section{Discussion}

In this paper, we improve our understanding of factors that shape individuals' foreign policy attitudes and preferences. As expected, we find that belonging to a certain generation is a very influential source. In case of public opinion towards Iran deal, the line between approving and disproving of the deal falls along generation lines. The Americans who were at least 19 years old in 1979 and thus constitute the hostage crisis generation are significantly less supportive of the 
deal and peaceful policies toward Iran in 2015 than people who were too young then to be interested in international affairs. This pattern holds up even when we control for what is known as the main determinants of foreign policy opinion, namely ideology and partisanship, and other demographic and media factors.

Neither gender, nor education, nor religion appear to be significant predictors of foreign policy attitudes, contrary to what some scholars suggest (Glazier 2013, Taydas, Kentmen and Olson 2012, Fite, Genest and Wilcox 1990, Holsti 2004, Wittkopf 1990). Interestingly enough, the analysis confirms that the media clearly plays some role in shaping public opinion on foreign politics. On the one hand, it is a surprising finding considering that the media effect is highly contested in the literature (Holsti and Rosenau 1984). On the other hand, one would expect to see the media among the most powerful drivers of anti-Iranian sentiments because not only do the media play a crucial role in promulgating a bad image of Iran today, but they also were actively providing a negative coverage at the time of the hostage crisis. Only four days after the crisis broke out, ABC commenced a special late-night news show, The Iran Crisis: America Held Hostage, with Ted Koppel as the host, which was dedicated exclusively to covering the crisis and providing daily updates on it (Vaughn 2008). ${ }^{6}$ On CBS, Walter Cronkite, a popular host of a news program, was "signing off his newscast each night with the number of days the hostages had been held in captivity" (Houghton 2001, 2) to pressure the Carter administration to resolve the crisis.

For many Americans, the hostage crisis was the first encounter with the Iranians. The majority of the population knew no difference between the Persians and the Arabs, nor did they distinguish between Sunni and Shia. "Unlike Iran's revolutionaries, who had a clear image of America's

\footnotetext{
${ }^{6}$ The show continued later as Nightline.
} 
pattern of behaviour, the Americans lacked any real reference point for the new reality in Iran" (Emery 2013, 4). Needless to say, the Iranians left an appalling first impression. Pictures of the students' attacking the embassy and crowds chanting "Marg bar Amrika" ("Death to America") and burning American flags in the streets of Tehran were constantly aired by the late-night news shows in the US. It was these pictures that frightened the nation and created the image of "crazy" Iranians, or the "mad mullahs," which would prove to be the most powerful and long-living stereotype of the Iranians for the Americans decades later.

The results of our analysis show that the hostage crisis generation expresses significantly more negative attitudes to Iran deal and prefers more aggressive policies than does the post-hostage crisis generation. The question is why do we observe such a difference between the two generations?

For one reason, American news shows covering the hostage crisis were aired late at night when children and teenagers were already sleeping (the ABC's show, for example started at 11:30pm), thus their viewership base was naturally restricted to adults.

For another reason, unlike the majority of international crises that are rarely followed by and look distant to the domestic audience (Potter and Baum 2010), the hostage crisis became not only the "nation's most important business" (Harris 2004, 215) but also part of ordinary people's everyday lives. Late-night shows were covering the events in Iran very closely. The news coming from Tehran were deeply disturbing and shocking for the Americans. In their eyes, imageries and footages of aggressive students raiding the American embassy was equivalent to seeing the enemy seizing the American land itself. Seeing captured American citizens "with their hands bound and their eyes blindfolded and [being] forcibly prevented to communicate with one another" (Limbert 
2009) was equal to seeing their countrymen falling innocent victims of a foe that was not only cruel but also "devious, mendacious, fanatical, violent, and incomprehensible" (Limbert 2009, 186).

Furthermore, the events of November 1979 in Tehran were by no means ordinary for not only the Americans but also the history of diplomacy. The US had never faced such an unprecedented act of open anger and rage before and did not know how to react in the new circumstances. President Carter described the shock of those days in an interview in 1982: "I guess for six hundred years of recorded history as far as I know a host government has never endorsed or condoned the abuse or attack or kidnapping of a nation's emissaries and diplomats. This was a departure from historical precedent" (Carter 1982, 38). The first reaction of the Americans to the events of 1979 was a "stunned surprise" (Houghton 2001) that turned into hatred and protests. Houghton (2001) recalls that people in the US took it to the streets to express their feelings in the same manner as the Iranians did during the revolution: by burning flags of the other country. When the 1980 US rescue mission to free the hostages failed, leaving behind bodies of 8 military servicemen and confidential documents in Tabas desert in Iran, this hatred increased even more.

The US developed distrust in Iran as a result of the dramatic standoff in November 1979. The hostage crisis was and stays the cornerstone of its relationship with Iran that still "casts its long shadow over how America and Americans view Iran” (Limbert 2009). The Iranians, however, lost their trust in the US way earlier - in 1953, when the CIA backed a coup d'état in Iran to prevent nationalization of the country's oil. The crisis of 1953 was the defining moment of the Iranians' attitudes toward the US. Unlike the American people and policy makers whom the events of 1979 caught off guard, the Iranian students who attacked the embassy had a clear and very unfavorable image of the Americans in their minds. Khomeini's reference to the US as "the Great Satan" was 
quite a precise description of popular sentiments in revolutionary Iran. In sum, "[t]he two crises [...] explain much of the hostility, mistrust, fear, and suspicion that today pervade each side's view of the other" (Limbert 2009).

The attack on the American embassy left such a bad first impression on adult Americans that they keep giving the Iranians short shrift even decades later. The Americans, witnessing the unfolding drama of 1979 in front of their TVs, learned one thing: the Iranians are not to be trusted. The image of the Iranians quickly became associated with "fanaticism, violence, irrationalism, self-destruction, and disregarding for the norms of international relations" (Limbert 2009, 87). Subsequent events such as the attacks on the Buenos Aires Jewish centers, Beirut Embassy bombings, and President Ahmadinezhad's awkward behavior strengthened the myth of the "incomprehensible" Iranians engendered by the hostage crisis.

Despite the promising political atmosphere when the Iran nuclear agreement was reached in 2015, the American public never became less suspicious about Iran and its intentions. Gallup public opinion polls from 1989 to 2019 show that only an average of 12 percent of the Americans hold favorable attitudes to Iran. Moreover, nearly $60 \%$ of the Americans disproved of the agreement in 2016 (Gallup 2019). Therefore, Trump's abrupt withdrawal from the treaty was quite in line with public expectations. The idea of negotiating with the country that caused about the biggest insult to the US in the past did not sit well with many people. Barry Rosen (2016), one of the hostage survivors, summarized popular objections to the agreement: "[T]he Iranian regime that held my colleagues and me hostage has not reformed its ways. [...] The nuclear deal has done nothing to bring about crucial change in Iran. [...] The American government is foolish to ignore the growing threat that is Iran." 
Our research aptly reverberates with these widespread sentiments. Partisanship and ideology have their say in negative attitudes toward Iran prevailing among the Americans, but the roots of distrust and low support for any policy promising to walk past mutual hostility between the two countries ultimately lie in the events of 1979-1981. Even 40 years later, foreign policy attitudes and preferences of older generations of the Americans are strongly influenced by the hostage crisis. In other words, America is still held hostage - hostage of a bitter history and gruesome memories, the ghosts of which are alive and continue to define the relationship between the US and Iran. 


\section{References}

Barker, David C., Jon, Hurwitz, and Traci L. Nelson. 2008. "Of Crusades and Culture Wars: "Messianic" Militarism and Political Conflict in the United States." The Journal of Politics 70 (2): 307-332.

Baum, Matthew A., and Philip B. K. Potter. 2019. "Media, Public Opinion, and Foreign Policy in the Age of Social Media." The Journal of Politics 81 (2): 747-756.

Baum, Matthew A., and Philip B. K. Potter. 2008. "The Relationships Between Mass Media, Public Opinion, and Foreign Policy: Toward a Theoretical Synthesis." Annual Review of Political Science 11 (1): 39-65.

- 2015. War and Democratic Constraint: How the Public Influences Foreign Policy. Princeton, Oxford: Princeton University Press.

Baumgartner, Jody C., Peter L. Francia, and Jonathan S. Morris. 2008. "A Clash of Civilizations? The Influence of Religion on Public Opinion of U.S. Foreign Policy in the Middle East." Political Research Quarterly (2): 171-179.

Baxter, Sandra, and Marjorie Lansing. 1980. Women and Politics: The Invisible Majority. Ann Arbor: University of Michigan Press.

Brunner, Marco. 2018. During the 1979 hostage crisis, Iranians in the U.S. lived in fear of deportation. January 31. Accessed October 14, 2019. https://timeline.com/1979-hostagecrisis-iranians-in-us-lived-in-fear-of-deportation-97c450f3b7b3. 
Carpini, Michael X. Delli, and Scott Keeter. 1996. What Americans Know about Politics and Why It Matters. Yale University Press.

Carter, Jimmy, interview by Miller Center Interviews. 1982. Interview with Jimmy Carter (November): 38 .

Chun, Susan. 2015. Six things you didn't know about the Iran hostage crisis. July 16. Accessed October 14, 2019. https://www.cnn.com/2014/10/27/world/ac-six-things-you-didnt-knowabout-the-iran-hostage-crisis/index.html.

Cohen, Bernard. 1994. "A View from the Academy." In Taken By Storm: The Media, Public Opinion, and U.S. Foreign Policy in the Gulf War, by Lance W. Bennett and David L. Paletz, 9-10. Chicago: University of Chicago Press.

—. 1963. The Press and Foreign Policy. Princeton: Princeton University Press.

Converse, Philip E. 1964. "The nature of belief systems in mass publics." In Ideology and Discontent, by D. E. Apter. New York: Free Press of Glencoe.

Davidson, Lawrence. 2009. Foreign Policy, Inc.: Privatizing America's National Interest. University Press of Kentucky.

Destler, I. M., Leslie H. Gelb, and Anthony Lake. 1984. Out Own Worst Enemy: The Unmaking of American Foreign Policy. New York : Simon and Schuster.

Emery, Christian. 2013. US Foreign Policy and the Iranian Revolution : The Cold War Dynamics of Engagement and Strategic Alliance. Palgrave Macmillan. 
Fite, David, Marc Genest, and Clyde Wilcox. 1990. "Gender Differences in Foreign Policy Attitudes: A Longitudinal Analysis." American Politics Quarterly 18: 492-513.

Gallup. 2019. Iran. Gallup Historical Trends, Gallup. Accessed October 16, 2019. https://news.gallup.com/poll/116236/iran.aspx.

Glazier, Rebecca A. 2013. "Divine Direction: How Providential Religious Beliefs Shape Foreign Policy Attitudes." Foreign Policy Analysis 9 (2): 127-142.

Gries, Peter Hays. 2014. The Politics of American Foreign Policy: How Ideology Divides Liberals and Conservatives over Foreign Affairs. Stanford: Stanford Security Studies.

Harris, David. 2004. The Crisis: The President, the Prophet, and the Shah - 1979 and the Coming of Militant Islam. Little, Brown and Company.

Holsti, Ole R. 2004. Public Opinion and American Foreign Policy. The University of Michigan Press.

Holsti, Ole R., and James N. Rosenau. 1984. American Leadership in World Affairs: Vietnam and the Breakdown of Consensus. Boston: Allen\&Unwin.

Houghton, David Patrick. 2001. US Foreign Policy and the Iran Hostage Crisis. Cambridge: Cambridge University Press.

Hughes, Barry. 1978. The Domestic Context of American Foreign Policy. San Francisco: Freeman.

Huntington, Samuel P. 1996. The Clash of Civilizations and the Remaking of World Order. Simon $\&$ Schuster. 
Jelen, Ted G. 1994. "Religion and Foreign Policy Attitudes: Exploring the Effects of Denomination and Doctrine." American Politics Quarterly 22: 382-400.

Jeong, Gyung-Ho, and Paul J. Quirk. 2017. "Division at the Water's Edge: The Polarization of Foreign Policy." American Politics Research 47 (1): 58-87.

Kennan, George F. 1993. "Somalia, Through a Glass Darkly." New York Times, September 30: $\begin{array}{llll}00025 . & \text { Accessed } & \text { August } & 019,\end{array}$ https://www.nytimes.com/1993/09/30/opinion/somalia-through-a-glass-darkly.html.

Kertzer, Joshua D., Kathleen E. Powers, Brian C. Rathbun, and Ravi Iyer. 2014. "Moral Support: How Moral Values Shape Foreign Policy Attitudes." The Journal of Politics 76 (3): 825840.

Limbert, John W. 2009. Negotiating with Iran: Wrestling the Ghosts of History. U.S. Institute of Peace Press.

Livingston, Steven. 1997. Clarifying the CNN Effect: An Examination of Media Effects According to Type of Military Intervention. Cambridge, MA: Joan Shorenstein Barone Center, Harvard University.

Livingston, Steven, and Todd Eachus. 1995. "Humanitarian Crises and U.S. Foreign Policy: Somalia and the CNN Effect Reconsidered." Political Communication 12: 413-429.

Mandelbaum, Michael. 1994. "The Reluctance to Intervene." Foreign Policy 95: 16. 
Mandelbaum, Michael, and William Schneider. 1979. "The New Internationalism." In Eagle Entangled: U.S. Foreign Policy in a Complex World, by Keneth A. Oye, Robert J. Lieber and Donald Rothchild, 40-63. New York: Longman.

Mannheim, Karl. 1952. "Essays in the Sociology of Knowledge." By Paul Kecskemeti. London: Routledge and Kegan Paul.

Mayer, William G. 1992. The Changing American Mind: How and Why American Public Opinion Changed Between 1960 and 1988. Ann Arbor: University of Michigan Press.

Mueller, John E. 1973. War Presidents and Public Opinion. New York: Wiley.

Potter, Philip B. K., and Matthew A. Baum. 2010. "Democratic Peace, Domestic Audience Costs, and Political Communication." Political Communication 27 (4): 453-470.

Potter, Philip B. K., and Matthew A. Baum. 2013. "Looking for Audience Costs in All the Wrong Places: Electoral Institutions, Media Access, and Democratic Constraint." Journal of Politics 76 (1): 167-181.

Roberts, Adams. 1993. "Humanitarian War: Military Intervention and Human Rights." International Affairs 69: 446.

Rosen, Barry. 2016. "Iran Hostage Survivor: The Next U.S. President Must Be Hard-Line on Iran." Time, November 4. Accessed December 17, 2019. https://time.com/4556548/hostagesurvivor-iran-policy/.

Roskin, Michael. 1974. "From Pearl Harbor to Vietnam: Shifting Generational Paradigms and Foreign Policy." Political Science Quarterly 89 (3): 563-588. 
Schultz, Kenneth A. 2018. "Perils of Polarization for US Foreign Policy." Washington Quarterly 40 (4): 7-28.

Shapiro, Robert Y. Shapiro, and Harpreet Mahajan. 1986. " Gender Differences in Policy Preferences: A Summary of Trends from the 1960s to the 1980s." Public Opinion Quarterly 50 (1): 42-61.

Sharkey, Jacqueline. 1993. "When Pictures Drive Foreign Policy." American Journalism Review 15 (10): 14-19.

Smith, Terence. 1981. "Why Carter Admitted the Shah." In No Hiding Place, by Robert D. McFadden, Joseph B. Treaster and Maurice C. Carroll, 189-214. New York City: Times Books.

Taydas, Zeynep, Cigdem Kentmen, and Laura R. Olson. 2012. "Faith Matters: Religious Affiliation and Public Opinion About Barack Obama's Foreign Policy in the 'Greater' Middle East." Social Science Quarterly 93 (5): 1218-1242.

Togeby, Lise. 1994. "The Gender Gap in Foreign Policy Attitudes." Journal of Peace Research 34 (4): 375-392.

Vaughn, Stephen L. 2008. Encyclopedia of American Journalism. New York: Routledge.

Wittkopf, Eugene R. 1990. Faces of Internationalism: Public Opinion and American Foreign Policy. Durham, NC: Duke University Press.

Wittkopf, Eugene R. 1986. "On the Foreign Policy Beliefs of the American People: A Critique and Some Evidence." International Studies Quarterly 30: 425-445. 
Zaller, John. 1994. "Positive Constructs of Public Opinion." Critical Studies in Mass Communication 11 (3): 276-287. 
Appendix A. OLS model predicting Iran deal attitude $(N=932)$

\section{Model 1}

Coef. s.e.

Age in 1979 (ref=not born)

$1-6$

$7-12$

$13-18$

19-24

25-31

$32-38$

46 and more

PID (ref=indep)

Strong Rep

Not strong Rep

Lean Rep

Lean Dem

Not strong Dem

Strong Dem

Ideology (ref=ext.cons)

Cons

Slightly cons

Moderate

Slightly lib

Lib

Ext.lib

Christianity (ref=non-Christian)

Male (ref=female)

Media exposure (ref=don't follow)

Hardly interested

Somewhat interested

Very interested
$39-45$

$-0.02$

$-0.23$

$-0.26^{*}$

$-0.45 * * *$

$-0.40 * * *$

$-0.53 * * *$

$-0.42 * *$

$-0.28$

$-0.06$

$0.30 * *$

$-0.30 *$

$0.24^{*}$

$0.35 * * *$

$0.50 * * *$

0.05

0.18

$0.37 * *$

$0.44 * *$

$0.52 * *$

$0.66^{* * *}$

0.01

$-0.10$

0.28 *

$0.44 * * *$

$0.38^{* * *}$

$-0.14$

$-0.17$

$-0.25^{*}$

$-0.35$

0.22

$R^{2}$

High school

Some college

Bachelor's

Intercept

$N$

932
0.10

0.11

0.10

0.09

0.10

0.11

0.13

0.16

0.11

0.10

0.12

0.12

0.09

0.10

0.13

0.15

0.13

0.16

0.16

0.21

0.07

0.06

0.13

0.12

0.12

0.12

0.12

0.12

0.20 
Source: 2015 Chicago Council Survey of American Public Opinion and U. S. Foreign Policy 2015.

Notes: $* \mathrm{p}<0.05, * * \mathrm{p}<0.01, * * * \mathrm{p}<0.001$. 
Appendix B. OLS models predicting Iran-related policy preferences ${ }^{+}(N=961)$

\section{Model 1}

Coef $\quad$ s.e.

\section{Model 2}

Coef. s.e.

$-0.20 * * * \quad 0.05$

$-0.11^{*}$

0.05

Hostage crisis

generation (ref=post-

hostage crisis generation)

PID (ref=indep)

Strong Rep

Not strong Rep

Lean Rep

Lean Dem

Not strong Dem

Strong Dem

Ideology (ref=ext.cons)

Cons

Slightly cons

Moderate

Slightly lib

Lib

Ext.lib

Christianity (ref=non-

Christian)

Male (ref=female)

\section{Media exposure}

(ref=don't follow)

Hardly interested

Somewhat interested

Very interested

Education (ref=less than

high school)

High school

Some college

Bachelor's

Intercept
$R^{2}$
$N$

$\begin{array}{ll}-0.52 * * * & 0.10 \\ -0.30 * * * & 0.09 \\ -0.25 & 0.13 \\ -0.14 & 0.12 \\ -0.27 * * & 0.09 \\ -0.26 * * & 0.10\end{array}$

$-0.05$

$-0.02$

0.16

0.23

$0.45^{* *}$

0.33

0.14
0.16
0.15
0.17
0.16
0.21

0.14

0.15

0.17

0.21
0.05

Model 3

Coef. s.e.

$\begin{array}{llll}-0.51 * * * & 0.10 & -0.42^{* * *} & 0.10 \\ -0.29 * * & 0.97 & -0.25^{*} & 0.10 \\ -0.24 & 0.13 & -0.14 & 0.13 \\ -0.12 & 0.12 & -0.04 & 0.12 \\ -0.25 * * & 0.09 & -0.21 * & 0.09 \\ -0.24 * & 0.10 & -0.18 & 0.09\end{array}$

-0.02
-0.01
0.15
0.21
$0.44 * *$
0.31

0.14

$-0.03$

0.14

0.16

$-0.01$

0.15

0.15

0.11

0.14

0.17

0.17

0.16

0.17

$0.39 *$

0.16

0.21

0.18

0.21

$-0.17 * * \quad 0.06$

$-0.11 * \quad 0.05$

$\begin{array}{ll}-0.01 & 0.12 \\ -0.27 * & 0.10 \\ -0.42 * * * & 0.11\end{array}$

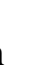

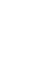

\footnotetext{
Source: 2015 Chicago Council Survey of American Public Opinion and U. S. Foreign Policy 2015.
} 
Notes: $* \mathrm{p}<0.05, * * \mathrm{p}<0.01, * * * \mathrm{p}<0.001$.

${ }^{4}$ Factor scale associating lower values with aggressive and military policy preferences, and higher values with peaceful and diplomatic policy preferences. 